\title{
THE EFFECT OF DIETARY LEVELS OF CALCIUM, PHOSPHORUS AND CHOLECALCIFEROL ON PERFORMANCE, CARCASS AND TIBIA CHARACTERISTICS OF BROILER CHICKS
}

\author{
A.I. El-Faham; S.A. Ibrahim; H.A. El-Alaily and H.A. Thabet \\ Poultry Production Dept., Fac. of Agric., Ain Shams Univ., Egypt
}

\section{SUMMARY}

\begin{abstract}
A study was conducted to determine the effect of increasing dietary cholecalciferol in deficient calcium and phosphorus broiler diets on productive performance, carcass characteristics and some tibia measurements. A total of 270 one day old Hubbard chicks were weighed and randomly allocated into a completely randomized design (five treatments, six replicate groups, nine chicks in each group). The experimental diets were as follows: (T1) control diet, was formulated according to the manual guide of Hubbard broiler chicks. (T2 to T5) tested diets were containing half of the calcium and available phosphorus requirements with extra levels of cholecalciferol 5000 (T2), 6000 (T3), 7000, (T4) and 8000 (T5) international units. The main results obtained can be summarized as follows: At 6 weeks of age, body weight and gain of birds fed either control or deficient calcium and phosphorus diets with 7000 (T4) and 8000 (T5) I.U. of cholecalciferol were significant heavier than those with 5000 (T2) or 6000 (T3) and consume less feed and gave better feed conversion ratio. The highest production efficiency factors were recorded for the control and T5 groups. Carcass characteristics (dressing \% and ready to cook \%) were significantly higher in birds fed control or those fed T4 and T5 diets compared with that fed T2 and T3 diets. Tibia breaking strength, tibia length and width of birds fed control or T5 diets were higher than other treatments with significant differences. It could be concluded that using the half requirements of calcium and available phosphorus in broiler diets supplemented with $8000 \mathrm{IU} / \mathrm{kg}$ cholecalciferol would have a positive effect on the cost of production of broiler chicks, without any adverse effect on productive performance, carcass and tibia characteristics.
\end{abstract}

Keywords: Calcium, Phosphorus, Cholecalciferol, Performance, Tibia characteristics, broiler

\section{INTRODUCTION}

Broiler diets are prepared mainly from plant feedstuffs like corn, wheat and soybean meal, these feedstuffs are containing phosphors in the form of phytate phosphorus. These phytate are not fully hydrolyzed by the endogenous enzymes of poultry, which lead to poorly available phosphorus in plant feedstuffs (Cromwell and Coffy, 1991).

Moreover, Phytate phosphorus utilization is affected by both dietary calcium and phosphorus levels (Mohamed et al., 1991), and the great effect is due to the calcium level.

On the other hand, diets deficient in phosphorus depressed growth rate and feed efficiency (Fernandes et al., 1999; Li et al., 2000). Also, (Ibrahim et al., 1999) reported that average body weight was reduced with low phosphorus levels.

In growing diets, it is extremely important to have calcium to available phosphorus ratio of $2: 1$ respectively (Schwartz, 1996).

Excess calcium is excreted as a calcium-phosphorus (Ca-P) complex, which can result in a phosphorus deficiency if too much of the complex leaves the bird (Korver, 1999).

Also, Ballam et al., (1985) confirmed that chicks fed diets containing $0.85 \%$ calcium hydrolyzed more phytate than those fed $1 \%$ calcium in the diets, Mohamed et al., (1991) found that phytate phosphors utilization was achieved by $15 \%$ when reducing dietary calcium from $1 \%$ to $0.5 \%$.

Vitamin D3 $\left[1,25(\mathrm{OH})_{2} \mathrm{D}_{3}\right]$ enhances the intestinal absorption of both calcium and phosphate by stimulate calcium binding proteins, and acts on the kidneys to stimulate absorption of calcium and 


\section{El-Faham et al.}

phosphorus from the kidney and the bone (Soares et al., 1995). The cholecalciferol supplementation of poultry diets increases phytic acid-P utilization (Mohammed et al. 1991)

However, the body weight gain decreased significantly with reduction in levels of Ca and NPP in diet compared to those fed reference diet (Rama Rao et al., 2008). The authors indicated that, supplementation of $\mathrm{D}_{3}$ to the low $\mathrm{Ca}$ and NPP diet, though improved the BWG significantly but not as the reference diet. The feed conversion ratio was not affected by concentrations of $\mathrm{Ca}$, NPP and $\mathrm{D}_{3}$ in diet at 5 wk of age. And it is concluded that higher levels of $\mathrm{D}_{3}$ supplementation to low $\mathrm{Ca}$ and NPP diets improved the performance partially but not as diets containing recommended levels of $\mathrm{Ca}$ and NPP. However Afsharmanesh and Pourreza (2005) fed low calcium and phosphorus diets supplemented with vitamin $\mathrm{D}_{3}$ and found that body weight of birds fed control diets were similar to those that received the calcium and phosphorus diets supplemented with vitamin $\mathrm{D}_{3}$.

Also results of Haq Nawaz et al., (2008) indicated that feed intake and live weight gain increased significantly during starter and finisher phases with increasing levels of cholecalciferol in the diet. Santos, Y et al. (2005) found that body weight was increased by $1.7 \%$ and feed conversion ratio was improved by $2.6 \%$ by using extra levels of vitamin $\mathrm{D}_{3}$ in broiler diets. Also, Bolu et al. (2006) reported that higher doses of cholecalciferol produced significant body weight gain and feed intake by at least $18 \%$ higher for birds fed high levels of cholecalciferol compared with birds fed control diets.

Utilization of calcium and phosphorus can be enhanced when they fed at suboptimal levels by adding extra levels of cholecalciferol in poultry diets (Qian et al., 1997) without any negative effects, because the cost of synthetic cholecalciferol is lower than that of inorganic phosphorus sources, reducing of dietary calcium and phosphorus with high concentration of cholecalciferol may be beneficial for reduce feeding cost as well as phosphorus pollution to the environment.

The objective of the present study was to investigate the effect of using high concentration of cholecalciferol in deficient calcium and phosphorus broiler diets on performance, some blood constituents, bone quality and carcass quality, and to determine which cholecalciferol level could be included in these deficient diets.

\section{MATERIAL AND METHODS}

The present study was carried out at the Poultry Nutrition Farm, Poultry Production Department, Faculty of Agriculture, Ain Shams University.

Two hundred and seventy unsexed day - old of Hubbard broiler chicks were obtained from a commercial hatchery (Cairo Poultry Company), randomly distributed into 5 treatments. Each treatment comprised of 54 chicks which divided into 6 replicates of 9 chicks each.

All chicks were reared in wire-floor batteries under similar environmental, managerial and hygienic conditions. Feed was presented in mash form in metallic feeders while an automatic nipple drinkers presented water both feed and water were provided ad-libitum.

Three periodical diets were formulated includes, starter from 1 to 14 days of age, grower from 15 to 28 days of age and finisher from 29 to 42 days of age. The control diet (T1) was formulated according to the manual guide of Hubbard broiler chicks which containing calcium $1 \%$, available phosphorus $0.5 \%$ and 3000 I.U cholecalciferol at the starter period and for the grower $(\mathrm{Ca} 1 \%$, A.P $0.5 \%)$ and the finisher $(\mathrm{Ca} 0.9 \%$, A.P $0.45 \%$ ) with the same level of cholecalciferol. Then tested diets were containing half of the calcium and available phosphorus requirements with graded levels of cholecalciferol 5000 (T2), 6000 (T3), 7000 (T4) and 8000 (T5) International unit (IU).

Crystalline cholecalciferol were obtained from Misr Feed Additives Company (MIFACO), the concentration of vitamin was 500000 I.U cholecalciferol / gram.

To insure proper mixing of crystalline cholecalciferol in diets, the vitamin was dissolved in $5 \mathrm{ml}$ ethanol to make a solution. A separate premix of cholecalciferol was prepared by mixing the above solution with soy oil and added to soy bean meal and then mixed with the respective experimental diets. 
Table (2): Effect of low levels of Calcium and phosphorus with high concentration of Cholecalciferol on broiler productive performance.

\begin{tabular}{|c|c|c|c|c|c|c|}
\hline $\begin{array}{l}\text { Experimental } \\
\text { diets }\end{array}$ & ${ }^{*} \mathrm{~T} 1$ & $\mathrm{~T} 2$ & $\mathrm{~T} 3$ & $\mathrm{~T} 4$ & T5 & Sig. \\
\hline \multicolumn{7}{|c|}{ Body weight (g) } \\
\hline Initial & $43.28 \pm 1.13$ & $43.52 \pm 1.61$ & $43.62 \pm 1.79$ & $43.25 \pm 1.82$ & $43.41 \pm 1.04$ & NS \\
\hline 6 weeks & $\begin{array}{c}2112^{\mathrm{a}} \pm 11.2 \\
\quad(100)\end{array}$ & $\begin{array}{c}1908^{\mathrm{b}} \pm 10.5 \\
(90.3)\end{array}$ & $\begin{array}{c}1912^{\mathrm{b}} \pm 11.5 \\
(90.5)\end{array}$ & $\begin{array}{l}2084^{\mathrm{a}} \pm 11.1 \\
\quad(98.7)\end{array}$ & $\begin{array}{c}2105^{\mathrm{a}} \pm 10.2 \\
(99.7)\end{array}$ & $*$ \\
\hline \multicolumn{7}{|c|}{ Body weight gain $(\mathrm{g})$} \\
\hline 0-6 week & $2069^{\mathrm{a}} \pm 10.5$ & $1864^{\mathrm{b}} \pm 10.5$ & $1868^{\mathrm{b}} \pm 10.4$ & $2041^{\mathrm{a}} \pm 10.1$ & $2061^{\mathrm{a}} \pm 10.8$ & $*$ \\
\hline \multicolumn{7}{|c|}{ Feed consumption ( g / bird ) } \\
\hline $0-6$ week & $\begin{array}{c}3972.5^{\mathrm{b}} \pm 11.55 \\
(100)\end{array}$ & $\begin{array}{c}4012.3^{\mathrm{a}} \pm 11.55 \\
(101)\end{array}$ & $\begin{array}{c}4009.2^{\mathrm{a}} \pm 11.55 \\
(100.9)\end{array}$ & $\begin{array}{c}3980.3^{\mathrm{b}} \pm 11.55 \\
(100.2)\end{array}$ & $\begin{array}{c}3979.2^{\mathrm{b}} \pm 11.55 \\
(100.2)\end{array}$ & $* *$ \\
\hline \multicolumn{7}{|c|}{ Feed conversion ratio ( $\mathrm{g}$ feed / g gain ) } \\
\hline 0-6 week & $\begin{array}{c}1.92^{\mathrm{b}} \pm 0.10 \\
(100)\end{array}$ & $\begin{array}{l}2.15^{\mathrm{a}} \pm 0.10 \\
\quad(111.9)\end{array}$ & $\begin{array}{l}2.14^{\mathrm{a}} \pm 0.10 \\
\quad(111.5)\end{array}$ & $\begin{array}{c}1.94^{\mathrm{b}} \pm 0.10 \\
(101)\end{array}$ & $\begin{array}{c}1.92^{\mathrm{b}} \pm 0.10 \\
(100)\end{array}$ & $* *$ \\
\hline \multicolumn{7}{|c|}{ Mortality ( number of chicks) } \\
\hline $0-6$ week & 1 & 1 & 1 & 0 & 1 & - \\
\hline $\mathrm{PEF}^{* *}$ & 262 & 211 & 213 & 256 & 261 & \\
\hline \multicolumn{7}{|c|}{ 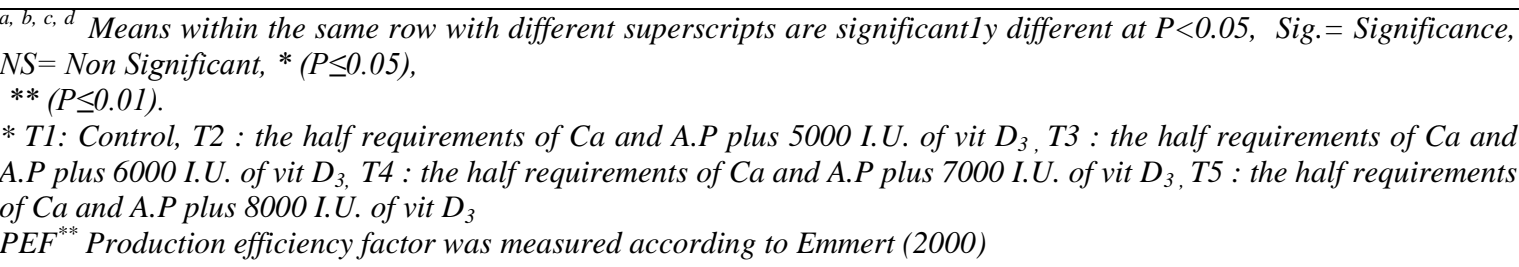 } \\
\hline
\end{tabular}

It is worth to note that chicks fed T2 and T3 diets during studied period (0-6 wks) reflected the lowest significant $(\mathrm{P}<0.05)$ results in both $\mathrm{LBW}$ and BWG compared with the other treatments $(\mathrm{T} 1, \mathrm{~T} 4$ and $\mathrm{T} 5)$.

On the other hand, chicks fed control diets (T1) gave insignificant slightly higher BWG compared to those fed (T4-5) diets being $2112 \mathrm{~g}$ vs. 2084 and $2015 \mathrm{~g}$ for (LBW) respectively and $2069 \mathrm{~g}$ vs. 2041 and $2061 \mathrm{~g}$, respectively. However, the differences failed to be significant. These results are agreement with those obtained by Rama Rao et al., (2008) who mentioned that significant improvement in body weight gain in birds fed low calcium and non-phytate phosphorus diet supplemented with cholecalciferol might due to increased availability or utilization of phytate phosphorus and calcium at higher concentration of cholecalciferol supplementation. The same trend were observed by Papesova et al., (2008) and Haq Nawaz et al., (2008). Also our data are in harmony with those observed by Afsharmanesh and Pourreza (2005) who fed low calcium and phosphorus diets supplemented with vitamin $\mathrm{D}_{3}$ and found that body weight of birds fed control diets were similar to those that received the deficient calcium and phosphorus diets supplemented with vitamin $\mathrm{D}_{3}$. Increased activity of intestinal phytase (Onyango and Adeola 2008) and production of calcium binding protein (Underwood, 1981) with cholecalciferol supplementation might have respectively increased utilization of phytate phosphorus and calcium.

The hydrolysis of phytate phosphorus in response to $\mathrm{D}_{3}$ supplementation agrees with the suggestion of Tanka and DeLca (1974) that $\mathrm{D}_{3}$ may be a phosphate transport hormone and that it generally stimulates the transport of phosphate at many points in the body. This idea would allow the postulation that intestinal phytases (phosphatases) (Maddaiah et al., 1964) may be greatly increases by the $\mathrm{D}_{3}$ supplementation and that once the phytates are hydrolyzed transport of the phosphate to the bone is facilitated by several transport systems from the mucosa to blood and from the blood to the bone (Edwards, 1993)

It clear upon data in Table (2) that the inclusion rate of 5000 (T2), and 6000 (T3) I.U cholecalciferol to deficient calcium and phosphorus diets doesn't match the optimal requirements of calcium and phosphorus. 
But inclusion rate of 7000 (T4) or 8000 (T5) I.U cholecalciferol to deficient calcium and phosphorus diet match the control diet (T1).

\section{Feed consumption (FC) and Feed conversion ratio (FCR)}

The obtained data show that, there were significant differences in FC and FCR among treatments during whole experimental period (0-6 wks) of age. It was obvious from (Table 2) that (FC) per chick (g) was significantly $(\mathrm{P}<0.01)$ increased by feeding ( $\mathrm{T} 2$ or $\mathrm{T} 3$ ) diets compared with those fed other dietary treatments T1, T4 and T5 and broiler chicks fed T2 diets gave the highest figure (4012.3 g) while, chicks fed control diets (T1) had the lowest figure (3972.5) and differences among treatments were significant.

Feed conversion ratio (FCR) showed the same trend since chicks fed control (T1) or (T5) diets were more efficient in converting their food into BWG compared with those fed other dietary treatments (T2-4). The best FCR was detected for the chicks fed, T1 and T5 (being the same figure 1.92, respectively) or T4 (1.94). On the other hand, the worst FCR were found in chicks fed T2 (2.15) or T3 (2.14) diets, which could be due to the lowest BWG and highest FC (Table 2). These results are in agreement with those reported by many investigators (Santos, Y et al., 2005; Bolu et al., 2006 and Haq Nawaz et al., 2008). They concluded that higher doses of cholecalciferol significantly increased feed consumption, live body gain and improved feed conversion ratio.

\section{Health conditions and mortality chick's number:}

Under the condition of the present study all chicks appeared healthy and the total mortality number was $4 / 254$ during the whole experimental period (0-6 wks) of age, without any clear differences among treatments.

\section{Productive efficiency factor (PEF):}

Resulted listed in Table (2), show the effect of different dietary treatments on PEF during whole experimental period (0-6 wks) of age.

It was noted that inclusion different levels of cholecalciferol to low levels of calcium and phosphorus in broiler diets (T2 to T5) compared with control group (T1) had clearly effect on studied parameters (PEF) and the corresponding values ranged between 262 and 211. The highest PEF was detected for the chicks fed control diets (262) or T5 diets (261).

On the other hand, the lowest PEF were found in chicks fed T2 (211), T5 (213) or T4 (256) diets.

\section{Carcass characteristics:}

Table (3) shows the effect of different dietary treatments on carcass characteristics for the chickens slaughtered at the end of $6 \mathrm{wks}$ of age. Experimental treatments with low levels of calcium and phosphorus with concentration of cholecalciferol (T2 and T3) had significant effect on most studied parameters compared with control group (T1) or T4 and T5. The corresponding values for dressing percentages ranged between 71.11 (T3) and 74.76\% (T5), while ready to cook (Hot carcass + giblets weight) percentages ranged between 75.56 (T3) and 79.39\% (T5). In addition, giblets percentages (liver + gizzard + heart) ranged between 4.45 (T2 and T3) and 4.63 (T5).

In general, chickens fed $\mathrm{T} 2$ or $\mathrm{T} 3$ diets gave the lowest dressing carcass, giblets and ready to cook percentages compared to those fed different dietary treatments (control or T4 and T5), respectively with significant differences between treatments except giblets $\%$.

\section{Tibia measurements:}

Data for some tibia measurements are summarized in Table (4).The obtained data showed that there were significant differences in tibia length $(\mathrm{cm})$, tibia width $(\mathrm{cm})$ and tibia breaking strength $\left(\mathrm{kg} / \mathrm{cm}^{2}\right)$ among treatments. Chicks fed T2 to T4 reflected the lowest tibia length and width, while chicks fed T2 andT3 reflected the lowest tibia breaking strength compared with other dietary treatments. On the other hand, chicks fed control diets or deficit calcium and phosphorus with 8000 IU cholecalciferol (T5) diets had significant higher tibia length, width and tibia breaking strength compared with other dietary treatments. The same trend was observed by Rama Rao et al. (2008) who reported that the relative weight of tibia, tibia breaking strength and tibia ash content decreased significantly with reduction in Ca and NPP levels in diet, and supplemental $\mathrm{D}_{3}$ appeared to replenish the tibia ash content and enhanced tibia weight and strength. Also 


\section{El-Faham et al.}

the finding of Santos et al. (2005) who indicated that tibia breaking strength and bones were stronger in high vitamin $\mathrm{D}_{3}$ diets than the control group. Also Baker et al. (1998) who found that with a $\mathrm{D}_{3}$ concentration of 1250 micro g/kg (250 times the recommended by the NRC) bone ash was increased significantly $(\mathrm{P}>0.05)$.

Table (3): Effect of low levels of Calcium and Phosphorus with high concentration of Cholecalciferol on Carcass characteristics.

\begin{tabular}{lcccccc}
\hline Item & T1 & T2 & T3 & T4 & T5 & Sig. \\
\hline Live body wt (g) & $2110^{\mathrm{a}} \pm 12.54$ & $1920^{\mathrm{b}} \pm 12.48$ & $1910^{\mathrm{b}} \pm 12.93$ & $2090^{\mathrm{a}} \pm 12.32$ & $2110^{\mathrm{a}} \pm 12.53$ & $*$ \\
Carcass wt (g) & $1547.26^{\mathrm{a}} \pm 5.14$ & $1375.48^{\mathrm{b}} \pm 5.17$ & $1358.20^{\mathrm{b}} \pm 5.22$ & $1541.58^{\mathrm{a}} \pm 5.11$ & $1577.43^{\mathrm{a}} \pm 5.52$ & $* *$ \\
Dressing (\%) & $73.33^{\mathrm{a}} \pm 0.33$ & $71.64^{\mathrm{b}} \pm 0.45$ & $71.11^{\mathrm{b}} \pm 0.55$ & $73.76^{\mathrm{a}} \pm 0.58$ & $74.76^{\mathrm{a}} \pm 0.49$ & $* *$ \\
Giblets (\%) & $4.48 \pm 0.25$ & $4.45 \pm 0.30$ & $4.45 \pm 0.28$ & $4.54 \pm 0.21$ & $4.63 \pm 0.32$ & NS \\
${\text { Ready to cook }(\%)^{*}}^{77.84 \pm 0.54^{\mathrm{a}}}$ & $76.09 \pm 0.64^{\mathrm{b}}$ & $75.56 \pm 0.71^{\mathrm{b}}$ & $78.30 \pm 0.30^{\mathrm{a}}$ & $79.39 \pm 0.68^{\mathrm{a}}$ & $* *$
\end{tabular}

$\overline{a, b}$ Means within the same row with different superscripts are significantly different at $P<0.05$ Sig. $=$ Significance, $\quad N S=$ Non significant, * $(P \leq 0.05), * *(P \leq 0.01)$.

Ready to cook $\%=($ Carcass weight + giblets weight $) \%$

Table (4): Effect of low levels of Calcium and Phosphors with high concentration of Cholecalciferol on Bone quality parameters at 6 week of age.

\begin{tabular}{lllllll}
\hline Item & T1 & T2 & T3 & T4 & T5 & Sig. \\
\hline Tibia Length $(\mathrm{Cm})$ & $9.68^{\mathrm{a}} \pm 0.07$ & $7.18^{\mathrm{c}} \pm 0.06$ & $7.15^{\mathrm{c}} \pm 0.07$ & $8.85^{\mathrm{b}} \pm 0.07$ & $9.49^{\mathrm{a}} \pm 0.07$ & $*$ \\
Tibia Width $(\mathrm{Cm})$ & $0.95^{\mathrm{a}} \pm 0.03$ & $0.71^{\mathrm{b}} \pm 0.08$ & $0.69^{\mathrm{b}} \pm 0.09$ & $0.78^{\mathrm{b}} \pm 0.03$ & $0.88^{\mathrm{a}} \pm 0.05$ & $* *$ \\
$\begin{array}{l}\text { Tibia Breaking } \\
\text { Strength }\left(\mathrm{Kg} / \mathrm{Cm}^{2}\right)\end{array}$ & $21.77^{\mathrm{a}} \pm 0.87$ & $14.21^{\mathrm{b}} \pm 0.74$ & $14.66^{\mathrm{b}} \pm 0.87$ & $21.05^{\mathrm{a}} \pm 0.87$ & $21.12^{\mathrm{a}} \pm 0.87 *$ \\
\hline
\end{tabular}

$\overline{a, b, c}$ Means within the same row with different superscripts are significantly different at $P<0.05$, Sig. $=$ Significance, NS= Not significant, * $(P \leq 0.05), * *(P \leq 0.01)$.

Upon data in Table (4) it's clear that either levels of 3000, 5000, 6000 or 7000 . I.U cholecalciferol doesn't match deficient calcium and phosphors diets as compare to the control or 8000 I.U cholecalciferol to maintain the bone quality of broiler in good condition.

\section{CONCLUSION}

We recommended to use the half requirements of calcium and available phosphorus in broiler diets supplemented with extra levels of cholecalciferol (8000 I.U/ kg feed) in order to reduce feeding cost as well as phosphorus pollution to the environment without any adverse effects on productive performance, carcass quality and bone quality characteristics.

\section{REFERENCES}

Afsharmanesh, M. and Pourreza, J. (2005). Effects of calcium, citric acid, ascorbic acid, vitamin D3 on the efficacy of microbial phytase in broiler starters fed wheat-based diets. I. Performance, bone mineralization and ileal digestibility. International Journal of Poult. Sci.. 2005. 4: 6, 418-424.

Baker DH, Biehl R.R. and Emmert J.L. (1998). Vitamin D requirement of young chicks receiving diets varying in calcium and available phosphorus. British Poultry Science, 39: 413-417 
Ballam GC, Nelson TS and Kirby LK. (1985) Effect of different levels of calcium and phosphorus on phytate hydrolysis by chicks. Nutrition Reports International, 32: 909-913.

Bolu, S.A.; Adebayo, C.A.; Aklilu, A. and Aderolu, Z. (2006). Increasing dietary cholecalciferol for improved broiler marketability. Animal Nutrition and Feed Technology. 6: 2, 223-228.

Cromwell, G.L. and Coffey, R.D. (1991). Phosphorus-a key essential nutrient, yet a possible major pollutant-its central role in animal nutrition. Biotechnology in the feed industry, 1, 133-145.

Duncan, D.B. (1955). Multiple range and Multiple F tests. Biometrics, 11: 1-42.

Edwards, H.M. Jr. (1993). Dietary 1,25-dihydroxycholecalciferol supplementation increases natural phytate phosphorus utilization in chickens. J. Nutr., 123:567-577.

Emmert, J. (2000). Efficiency of phase feeding in broilers. Proceeding, California Animal Nutrition Conference. Frenco California, USA.

Fernandes, J.I.M., F.R. Lima, J.R.C.X. Mendonca, I. Mabe, R. Albuquerque and P.M. Leal (1999). Relative Bioavailability of phosphorus in feed and agricultural phosphates for poultry. Poult. Sci., 12:1729-1736.

Haq Nawaz; Muhammad Shafiq; Muhammad Yaqoob; Muhammad Yousaf; Fawwad Ahmad (2008). Effect of cholecalciferol on performance and carcass characteristics of broiler chicks. Indian Veterinary Journal. 2008. 85: 8, 851-854.

Ibrahim, S., JP. Jacob and R. Blair (1999). Phytase supplementaion to reduce phosphorus excretion of poultry. J. of Applied Poul. Res. 8: 414-425.

Korver, D., (1999) . Prevention and treatment of tetany in broiler breeder hens. Ross Tech. Ross Breeders.

Li, Y.C., D.R. Ledoux, T.L. Veum, V. Raboy and S. Ert (2000). Effect of low phytic acid corn on phosphorus utilization, performance and bone mineralization in broiler chicks. Poult. Sci., 79:1444-1450.

Maddaiah, V. T., Kurnick, A. A., and Reid, B. L. (1964). Phytic acid studies. Proc. Soc. Exp. Biol. Med. 115: 391-393.

Mohamed A, Gibney M. J and Taylor T. G. (1991) The effects of dietary levels of inorganic phosphorus, calcium and cholecalciferol on the digestibilty of phytate-P by the chick. British Journal of Nutrition, 66: 251-259.

National Research Councel. (NRC). (1994). Composition of poultry feed stuffs. Nat Acad. Sci. Washington, D.C.

Onyango, E.M. and O. Adeola (2008). Dietary phytate (inositol hexaphosphate) regulates the activity of intestinal mucosa phytase Journal of Animal Physiology and Animal Nutrition., 93: 639- 646

Papesova, L.; Fucikova, A.; Pipalova, M.; Tupy, P (2008) .The synergic effect of vitamin D3and 25hydroxy-cholecalciferol/calcidiol in broiler diet. Scientia Agriculturae Bohemica.. 39: 3, 273-277.

Qian H, Kornegay ET and Denbow DM.(1997). Utilization of Phytate phosphorus and calcium as influenced by microbial phytase, cholecalciferol, and the calcium: total phosphorus ratio in broiler diets. Poultry Science., 76: 37-460

Rama Rao, S.V., M.V.L.N. Raju, A.K. Panda, P.N. Saharai, M.R. Reddy, G.S. Sunder and R.P. Sharma (2008). Effect of surfeit concentration of vitamin $\mathrm{D}_{3}$ on performance, bone mineralization and mineral retention in commercial broiler chicks. The Journal of Poultry Science, 45:25-30.

Santos, Y.; Soto-Salanova, M.F. (2005). Effect of Hy-DReg. addition on performance and slaughterhouse results of broilers. Proceedings of the $15^{\text {th }}$ European Symposium on poultry nutrition, Balatonfured, Hungary, 25-29 September 2005. 219-221.

SAS Institute. (2002). Statistical Analysis System, SAS User's Guide: Statistics. SAS Institute. Inc.Editors, Cary, NC. USA.

Schwartz, R.W. (1996). Practical aspects of calcium and phosphorus nutrition. Avian Farms Technical Newsletter April, 1996. Avian Farms, INC.

Soares, J.H., J.M. Kerr and R.W. Gray (1995). 25-Hydroxycholecalciferol in poultry nutrition. Poult. Sci. 74:1919-1934. 


\title{
El-Faham et al.
}

Tanka, Y. and H.F. DeLuca (1974). Role of 1,25-dihydroxyvitamin $\mathrm{D}_{3}$ in maintaining serum phosphorus and curing rickets. Proc. Nat. Acad. Sci. U.S.A. 71:1040-1044.

Underwood, E.J.U., (1981). The Mineral Nutrition of Livestock (Second edition). Commonwealth Agricultural Bureau. England, United Kingdom. 31-43.

\section{تأثير مستويات مختلفة من الكالسيوم والفوسفور وفيتامين د3 على الأداء الإنتاجي وصفات الأبيحة وعظمة الساق}

\author{
أحمد إبر اهيم الفحام- سيد عبدالرحمن إبراهيم- حسين العلايلي- هاني على ثابت مطاوع

